\title{
TRUST INVESTMENT PROVISIONS WHICH HAVE WORKED WELL
}

\author{
Gilbert T. Strphenson*
}

The quality of the investment of trust funds, after all, depends in no small degree upon the investment provisions of the will or trust agreement under which the trust is being administered. The law gives testators and settlors the right largely to "write their own ticket" with respect to the trust investments. Testators and settlors, by means of wise investment provisions, can make it possible for the trustee to do its best job in the investment of trust funds and, on the other hand, by means of unwise investment provisions, can make it impossible for the trustee to do a first-class job. For example, the trustee simply cannot render its best service if, by the investment provisions of the will or trust agreement under which it is acting, it is directed to retain investments which, it knows, it should dispose of or is directed to dispose of investments which, it knows, it should retain. But the trustee can have no reason or excuse for not rendering the best trust investment service it knows how to render if by the terms of the will or trust agreement it is authorized to acquire, retain, and dispose of trust investments in the exercise of its best judgment.

Accordingly, any consideration of the law of trust investments should embrace a consideration of how the testator or settlor can best "legislate" in respect to trust investments by the investment provisions that he has written into his will or trust agreement.

In the preparation of a lecture which I delivered during the school year $1937-38$ to the upper classmen of nineteen American law schools, including Duke University, I made a factual study of the investment provisions of wills and trust agreements which, in the experience of men who have had to administer trusts under them, have worked well and a factual study of other provisions which, in their experience, have not worked well but, instead, have given trouble. In this lecture ${ }^{1}$ I made little or no

\footnotetext{
- A.B., 1902, A.M., 1904, Wake Forest College; A.M., 1906, LL.B., 1910, Harvard University. Director, Trust Research Department, Graduate School of Banking, American Bankers Association. Chairman, Committec on Policy and Program, Section of Real Property, Probate and Trust Law, American Bar Association; Past President, Trust Division, American Bankers Association. Author: Guide Posts in Preparing Wills (with A. H. Eller); Living Trusts; Wills; Life Story of a Trust Man; English Executor and Trustee Business; What a Life Insurance Man Should Know about Trust Business; The American System of Trust Business; Studies in Trust Business; Discretionary Powers of Trustees under Wills and Trust Agreements; Investment Provisions of Wills and Trust Agreements.

${ }^{2}$ Investment Provisions of Wills and Trust Agreements (The Graduate School of Banking, Am. Bankers Ass'n, 1938).
} 
attempt to pass judgment on these provisions but, instead, merely presented the conclusions of the men who had been called upon to administer trusts under these provisions. Now, as my contribution to this symposium on the investment of trust funds, I am venturing to suggest certain trust investment provisions which, in my judgment, will prove to be helpful to trustees.

The investment provisions of wills and trust agreements may be grouped under five heads as follows: (I) originals, (2) investments acquired from general estate, (3) new investments, (4) the investment powers of substitute or successor trustees, and $(5)$ the investments of co-trustees.

\section{Originals}

An original, in the generally understood terminology of trustees, is a stock or bond or mortgage or any other item of property which is turned over to the trustee at the time the trust is established or later; the term is used in contradistinction to property acquired by the trustee, which latter is known as a new investment. In a vast majority of trusteeships under will and in a great many living trusts, the stocks, bonds, and mortgages delivered to and taken over by the trustee at the time the trust is set up are not such as the trustee would be authorized, either under the general law or by the terms of the instrument, to invest in de novo. The general rule of law, subject to certain statutory exceptions, is that, when a trustee takes over originals which are not authorized trust investments, it must convert the originals into authorized investments within a reasonable time unless it has express authority under the instrument to retain such originals. Yet in the vast majority of cases, the testator or settlor would authorize the trustee to retain the originals if the matter were called to his attention at the time the will or trust agreement was being drawn.

Ordinarily it is unwise for the testator or settlor to direct the trustee either to retain or to dispose of originals, for after the trust has been set up it may turn out to be highly inadvisable to retain in certain cases or to dispose of the originals in other cases. What the creator of the trust really should do and what he actually does in most cases when the matter is called to his attention is to authorize, not direct, the trustee to retain originals as long as to the trustee, in the exercise of its judgment, it seems best to retain them, with the implied or expressed authority to dispose of them as and when the trustee thinks they should be disposed of. The following provisions authorizing the retention of originals is suggested:

To retain, without liability for loss or depreciation resulting from such retention, original property, real or personal, at any time received by it from the settlor (or executor) for such time as to it shall seem best, although such property may not be of the character prescribed by law or by the terms of this instrument for the investment of other trust funds and although it represents a large percentage of the total property of the trust estate; and to dispose of such original property by sale or exchange or otherwise as and when it shall deem advisable and receive and administer the proceeds as a part of the trust estate; and, if non-income-producing property is retained, then upon the sale, exchange, or other disposition of such property, to make a reasonable apportionment of the proceeds between income 
and principal so as to make up for the loss of income during the period of retention of the unproductive property.

Three clauses in the above provision call for comment. They are: "Without liability for loss or depreciation resulting from such retention," "although it represents a large percentage of the total property of the trust estate," and "reasonable apportionment of the proceeds" of non-income-producing property.

The "without liability" clause does not mean and should not mean that the trustee is without liability under any and all circumstances for loss or depreciation with respect to these originals. Such an exculpatory provision should not be depended upon to relieve the trustee of liability where the conduct of the trustee has been below the standard of the reasonably prudent man holding originals for such time as to him it seems best.

The reference to the originals' representing a large percentage of the total property makes it clear that the testator or settlor is aware that the retention of the originals is apt to throw the trust estate out of balance and prevent what otherwise would be proper diversification. Where the testator's or settlor's estate is composed overwhelmingly of a few favorite stocks or bonds, it is well for him, by some such provision, to make it clear that he knows the trustee in exercising its authority to retain originals may have to disregard its usual practice of diversification.

If the trustee is to retain non-income-producing property, then it is but fair that, when such property is sold, the income-beneficiaries should share on some fair basis in the proceeds of the sale.

\section{Investments Acquired from General Estate}

Very frequently, particularly in connection with life insurance trusts, the settlor, if the matter is called to his attention, will wish to authorize, not direct, the trustee under his life insurance trust agreement to make purchases from, or to make loans to, the executor under his will, so as to provide the executor funds with which to pay debts, taxes, and administration expenses. If the money for these purposes is raised by means of a loan by the trustee to the executor, secured by stocks, bonds, or mortgages belonging to the general estate, then the only interest that the trustee would have in such stocks, bonds, or mortgages would be in case the executor could not pay off the loan and the trustee had to realize on its collateral. But where the money is raised by means of a purchase from the executor, then the stocks, bonds or mortgages acquired may and are likely to be, some of them at least, investments that would not be proper for the trustee to make in the first instance.

The following provisions are suggested to cover such purchases from or loans to the executor under the will by the trustee under the life insurance trust agreement or, less frequently, under the living trust agreement:

To Make Purchases from General Estate. To acquire by purchase, exchange, or otherwise property, real or personal, from the executor, administrator, or testamentary trustee of the settlor's estate although such property may not be of the character prescribed by law or by the terms of the trust instrument for the investment of other trust funds and although 
the acquisition of such property may result in a large percentage of the trust estate being invested in one class of property, and, without liability for loss or depreciation, to retain the property so acquired so long as the trustee shall deem advisable.

To Make Loans to General Estate. To make loans, secured or unsecured, to the executor, administrator, or testamentary trustee of the settlor's estate upon such terms as to security, rate, maturity, and in other respects as the trustee shall deem advisable, and to retain the notes, bonds, mortgages, or other evidences of such indebtedness as trust investments without liability for loss or depreciation resulting therefrom.

\section{New Investments}

When it comes to new investments-the investment of new funds, whether resulting from cash additions to the trust or sales or maturities-the testator or settlor has five choices with respect to the investment provisions of the will or trust agreement. He may keep silent about the investment of new funds, in which case the trustee will have to follow the trust investment statutes. or cases or rules or practices of the jurisdiction in which the trust is being administered. He may specify the investments or the classes or types of investments. He may say that his trustee shall invest and reinvest new funds in legals only. He may say that his trustee may invest and reinvest according to its own judgment and discretion, whether in legals or nonlegals. These choices now are to be considered in the order named.

Unless the testator or settlor knows what to say about investments, he had better say nothing and let the law take its course. The trustee can do a better job operating under the law than under too restrictive or too directive investment provisions.

It is ordinarily unwise to say just what stocks or bonds the trustee shall invest in. However, in those states that do not have a list of legals, it is wise to indicate, in general terms of course, the types or classes of investments the testator or settlor authorizes the trustee to make. The following provision is suggested:

The trustee is hereby authorized and empowered to hold and possess and to manage, invest, reinvest and keep invested all and every part of the trust estate which may come into its possession in the following classes of securities, and no. other:

(r) In notes or bonds secured by first liens on improved real property, which real property is appraised by the trustee or its authorized representatives at the time of such investment at a value at least double the amount of the first lien notes or bonds secured thereby;

(2) In any bonds, notes or certificates issued by the United States, or guaranteed by it;

(3) In the bonds of any state, county, parish, city, town, school district (independent or common), or other municipal corporation in the United States which shall not, during a period of ten years prior to such investment, have defaulted in the payment of either the principal or interest on any of its bonded obligations; or

(4) In the first mortgage bonds or first mortgage notes of any industrial, utility or railroad company operating in the United States.

In those states in which there is a statutory list of legals or in which there is statutory provision authorizing some governmental body to make up a list of legals, the testator or settlor frequently has written into his will or trust agreement a pro- 
vision that the trustee in the investment of new funds shall be limited to legals. Such a provision is simple and may be worded as follows:

The trustee is authorized to invest and reinvest only in such securities as are authorized by the laws of the State of............. for trust investments.

A real problem arises, however, out of such a provision as the foregoing if it is . written into a will or trust agreement creating a trust that is to be administered in a state that does not have a list of legals. Only about half of the states do have such a list. North Carolina is one of the states that do not have a legal list. Suppose, then, the draftsman of a North Carolina will or trust agreement writes into the instrument a provision that the trustee is to invest only in legals. What are legals in North Carolina? There is no statutory list, no statutory provision for having a governmental body, like the state banking department, make up from time to time and publish a list, no provision for the promulgation of a legal list by order of court, no legal list by any interpretation. In such a case, perhaps, it would be held that the trustee would be restricted to such investments as the reasonably prudent man would make in the investment of his own funds with a view to the safety of the principal and to the steadiness of the income and not to speculation-really the rule laid down in the case of Harvard College v. Amory. ${ }^{2}$ But, in order to save such uncertainty and confusion, if the trust is to be administered in a state, like North Carolina, which does not have a list of legals, it is better to state in the trust instrument the general types and classes of investments which the trustee is authorized to make rather than to say that the trustee is authorized to invest only in legals.

In the vast majority of wills and trust agreements in which the trustee is a bank or trust company-that is, a corporation that makes a business of rendering trust service and holds itself out as a specialist, among other things, in the field of trust investment-the trustee is authorized, in the exercise of its own judgment and discretion, to select the trust investments, without being limited to legals or to investments generally understood to be appropriate for trustees to make. Here it really is the task of the testator or settlor, after the matter has been explained to him fully by the draftsman, to give his trustee such broad discretionary investment powers. The following provision would seem to cover the case:

To Invest and Reinvest. To invest and reinvest and keep the trust estate invested in any kind of property, real or personal, including by way of illustration but not of limitation, common and preferred stocks, voting trust certificates, bonds, notes, debentures, mortgages, shares or interests in investment trusts, shares or interests in common trust funds, investments that yield a high rate of income or no income at all, and wasting investments, - without regard to the proportion any such investment or investments of a similar character may bear to the total trust estate or whether or not such investments are in new issues or in new or foreign enterprises, and without being limited to the classes of investments in which trustees are or may be authorized by statute or case or rule of court to invest trust funds; intending hereby to authorize the trustee to act in such manner as it shall believe to be for the best interest of the trust estate, regarding it as a whole, even though particular investments otherwise might not be proper.

'9 Pick. 446 (Mass. 1830). 
This is about as broad an investment power as it is possible to grant. Yet, broad as it is, the trustee still is held to the standard of care, skill, and caution of the prudent man investing his own property having primarily in view the preservation of the estate and the amount and regularity of the income to be derived therefrom. ${ }^{3}$ Certain types of investments-for example, common and preferred stocks, investment trusts, common trust funds, high-yield or no-yield investments, and wasting investments-are singled out and mentioned by name because in some jurisdictions authority to a trustee to invest in its own discretion is construed to mean discretion within the legal list. In these and in all other jurisdictions, for that matter, a trustee hesitates to invest in unusual types of securities unless they are mentioned by name as being within the authorized classes.

Another provision giving the trustee broad investment powers, which has certain advantages over the one just suggested, is the following:

The trustee is authorized to invest and reinvest the trust funds from time to time, without restriction as to the kind or character of property in which such investments shall be made, and regardless as to whether or not such investments are those specifically authorized for trustees under the statute laws of the State of............ or of any other states to which the administration of my estate may be subject; and the trustee shall not be liable for any loss in any investment made by it except in cases where it would have been liable had the investment been one authorized by statute.

Three phrases in the foregoing provision call for special comment: (I) "without restriction as to the kind or character of property," (2) "any other state to which the administration of my estate may be subject," and (3) "except in cases where it would have been liable had the investment been one authorized by statute."

The phrase "without restriction as to the kind or character of property" certainly would not be construed by a prudent trustee, however it might be construed by a court in a given case, as a license to make investments other than those which a prudent man would make under the circumstances.

At a time when testators and settlors frequently move their domicil and shift their trusts from one jurisdiction to another, it is well to incorporate in the instrument the broadening clause, "any other state to which the administration of my estate may be subject."

Not infrequently the will or trust agreement states, in substance, that the trustee shall be "without liability" for investing in non-legals. The draftsman really does not mean this. He means only that, for the purposes of the trust in hand, the nonlegal is an authorized investment and that the trustee would be liable only as it would be liable with respect to any other authorized investment. So, the phrase "except in cases where it would have been liable had the investment been one authorized by statute" is true to the fact and, therefore, is preferable to a blanket nonliability clause.

Sometimes a trustee is authorized to invest new funds in either non-legals or legals, but is required to obtain beforehand the approval of some third party-the

- Restatement, Trusts (1935) \$227, comment $u$. 
settlor himself, or somebody designated by the settlor. In such case it is of the utmost importance that the instrument express clearly and unequivocably how the approval is to be given and what the trustee is to do in the event the approval is not forthcoming. Uncertainty or indefiniteness at this point is one of the all too frequent loose ends of the draftsmanship of wills and trust agreements that lead to confusion and sometimes to litigation. The following provision would seem to cover the case:

(Following the investment provisions authorizing the trustee to invest in legals only or in non-legals or legals in the exercise of its judgment, as the case may be)

However, the trustee is authorized to invest funds only with the approval of......... under the conditions set forth in this paragraph. Such approval shall be expressed in writing by the said............ In the event that the said..$\ldots \ldots \ldots$. shall not express his approval in writing within a period of........days after the trustee shall have submitted its recommendation' to him, the trustee shall proceed to make or not to make the investment in the exercise of its own judgment. In the event of the death, or illness, or incapacity, or absence of said............. so that his approval cannot be given within the said....... days, the trustee shall proceed to make or not to make the investment in the exercise of its own judgment.

The foregoing provision puts to rest any question as to how the third party is to express his approval. It also settles the question as to what the trustee is to do in case the third party cannot or will not give his approval.

\section{Investment Powers of Successor or Substitute Trustees}

Another point that should, by all means, be covered in the investment provisions relates to the investment powers of successor or substitute trustees. This arises in connection with both individual and corporate trustees.

The testator or settlor names a bank or trust company and an individual cotrustee and gives them broad discretionary investment powers. In one case he makes no provision for a successor trustee to the individual in the event of the death or incapacity or resignation of the latter. Does he mean that, after the retirement of the individual trustee, the corporate trustee shall exercise the same broad investment powers or that, after that, it shall be limited to legals? In another case, the testator or settlor does make provision for a successor to the individual trustee but fails to make any mention of the carry-over of the investment powers to the successor trustee. Both of these points should be covered in the will or trust agreement.

The first point may be covered in this way:

In the event of the death, incapacity, or resignation of the said................. trustee, the said.............. (bank or trust company) as the sole remaining trustee shall have all the investment powers originally possessed by the said. and the said.................as co-trustees.

The second point might be covered this way:

Any successor or substitute trustee shall have all the investment powers and be subject to all the investment duties, responsibilities, and liabilities herein granted to or imposed upon the original trustee. 
But the problem of the investment powers of the successor or substitute trustee does not stop with the individual. It arises in connection with the bank and trust company as well. Two or more banks or trust companies merge or consolidate and either continue under the name of one of them or under a new name. Does the resulting bank or trust company have all the investment powers of the original trustee?

In most cases, no doubt, the testator or settlor naturally would wish the resulting bank or trust company to have all of the investment powers, as well as other powers, of the original bank or trust company. If so, then the following provision would seem to cover the case:

It is understood and agreed that any corporation or association which by reason of any merger, consolidation or transfer of assets may succeed to all, or substantially all, of the business of the trustee, automatically, and without the execution or filing of any instrument, or any further act, deed or conveyance on the part of any of the parties hereto, shall be and become successor of the trustee hereunder and vested with all of the title to the trust funds and it, as well as any other successor trustee hereunder, shall possess all the powers, discretions, immunities, and privileges as did the above named .............. Trust Company as the original trustee hereunder.

\section{Co-Trusteeships}

In connection with co-trusteeships-usually between a corporation and an individual-two points, at least, should be covered. One is, Who is to have custody of the securities? The other is, Are all the trustees to be jointly responsible and liable with respect to investments or are the investment duties, responsibilities, and liabilities to devolve upon only one of the trustees, usually the corporation?

It may save a great deal of trouble to have it specifically set forth in the instrument that the bank or trust company is to have sole custody of the securities. As a matter of fact, in most cases this is taken for granted and, if the matter were called to the attention of the testator or settlor, he would express definitely a direction on this point. The following provision would cover the case of custody of securities:

The said........... (bank or trust company) shall have sole custody of all cash and stocks, bonds or mortgages and other items of property that may become a part of the trust estate.

The trust corporations of England, Scotland, and Ireland cover this point rather more fully. The following provision from the official pamphlet of the Royal Bank of Scotland is typical:

That the said Bank shall have exclusive custody of all moneys, funds, properties and securities, certificates and documents of title to property of all kinds whatsoever, belonging or relating to my trust estate; but the other Trustees or Trustee hereunder shall be at liberty at reasonable times to examine in the hands of the said Bank the said securities, certificates and documents of title to property, and all accounts, reports and documents relating thereto, and the name of the said Bank, or its nominees or nominee company, shall be placed first on the Register of Proprietors of all registered stocks, shares and securities, or if the said Bank shall think proper, such stocks, shares and securities shall be registered in 
name of the said Bank or its nominees or nominee company alone, and in any case the said Bank or its nominees or nominee company shall be exclusively entitled to receive all dividends and interest thereon and to exercise all voting and other rights in respect thereof, and in case of any difference of opinion between the said Bank and the other Trustees or Trustee the opinion of the said Bank shall prevail and every appointment of a new Trustee shall be subject to the written consent of the said Bank.

With respect to the making of investments it is perhaps true that in a majority, but in no means all, of the cases the testator or settlor means that all the trustees, corporate and individual, shall be jointly responsible and liable with respect to investments. In all such cases, none of the trustees would be safe in making or changing an investment without the joinder of the others. If nothing is said about the investment responsibilities and liabilities of the respective trustees, they will be joint. However, in some cases the testator or settlor really does not mean that his individual trustee or trustees shall have investment duties, responsibilities or liabilities. For example, he does not mean that his wife shall have joint responsibility with the bank or trust company for making investments. He names her trustee only to keep her in touch with the administration of the trust or to put her in a position where she can help in the personal aspects of the trust's administration. If the matter were called to his attention, he would not think of burdening her with investment responsibilities and liabilities but, instead, would leave them up to the bank or trust company. In such a case a provision somewhat like the following, which is adapted from some of the Canadian trust instruments, would cover it:

... the appointment of said . . . is hereby made on the condition that he act as such in an advisory capacity only without remuneration and that the said trust company shall take upon itself the burden of the actual administration of my estate and of the trusts thereof as the duty of collecting in, converting, managing, investing and administering my estate, and the trust thereof shall rest with the said corporation.

In general, it may be said that the trust investment provisions which have worked well are the ones under which the trustee has been able to change its investment policies-not principles-from time to time to meet changing, ever-changing, economic and financial conditions. Ordinarily the better policy for the testator or settlor to adopt is to choose his trustee with the greatest of care and then give his trustee broad, discretionary investment powers, without much of specific direction or restriction. If he is not willing to give such powers to the trustee he has in mind then, maybe, the trouble is in the trustee, not the investment provisions, and he had better look further for a trustee in whose investment judgment he does have full confidence. Investment provisions, no matter how well they may be drawn, never can be a substitute for the trustee's investment knowledge, experience and-most important of all-investment judgment. 